\title{
Kegiatan preservasi naskah kuno Syekh Abdul Manan di Museum Bandar Cimanuk Indramayu
}

\author{
Ute Lies Siti Khadijah1, Lutfi Khoerunnisa2, Rully Khairul Anwar ${ }^{3}$, Ayu Apriliani ${ }^{4}$ \\ 1,2,3,4Program Studi Perpustakaan \& Sains Informasi, Universitas Padjadjaran \\ J1. Raya Bandung-Sumedang Km. 21, Jatinangor, Sumedang, Jawa Barat, 45363 \\ E-mail : '1ute.lies@unpad.ac.id, 2lutfi12002@mail.unpad.ac.id,3rully.khairul@unpad.ac.id, \\ 4ayu16014@mail.unpad.ac.id
}

Received: November 2020; Accepted: May 2021; Published: June 2021

\begin{abstract}
The spread of Islam in Indramayu stems from trading activities at Cimanuk Port, Indramayu. This is completely contained in the hundred years old manuscripts of Sheikh Abdul Manan. This study aimed to determine how the preservation of Syekh Abdul Manan's ancient manuscripts at the Bandar Cimanuk Museum, Indramayu. The research used a qualitative approach through descriptive research method. Based resulst of research, the Bandar Cimanuk Museum has carried out activities for the preservation of Sheikh Abdul Manan's ancient manuscripts through restrictions to direct access to museum users, routine cleaning of manuscripts and the museum environment, fumigation, and digitization. Restrictions to direct access to museum users by placing the ancient manuscripts in glass covered displays and special boxes. Routine maintenance of the museum is conducted by regulating the light and humidity, using camphor in every corner of the room, dehumidifier settings, and directing the museum visitors. Fumigation is conducted through pesticide compund to eliminate pests once a year. The digitization of ancient manuscripts into the form of a digital book (flipbook) which is carried out in collaboration with museums with various institutions, such as, a collaboration with researchers and students from Padjadjaran University. The entire process of preservation activities was carried out in a structured and panned methods. The study concludes that the importance of preservation to maintain and preserve the heritage of ancient manuscripts to be accessed and utilized by wider societies.
\end{abstract}

Keywords: Manuscripts; Preservation; Bandar Cimanuk Museum

\begin{abstract}
Abstrak
Penyebaran agama Islam di Indramayu bermula dari aktivitas perdagangan di Pelabuhan Cimanuk Indramayu. Hal ini tertuang secara lengkap dalam naskah kuno Syekh Abdul Manan yang berusia ratusan tahun. Penelitian ini bertujuan untuk mengetahui bagaimana kegiatan preservasi naskah kuno Syekh Abdul Manan di Museum Bandar Cimanuk Indramayu. Penelitian ini menggunakan pendekatan kualitatif melalui metode penelitian deskriptif. Berdasarkan hasil penelitian, pihak Museum Bandar Cimanuk telah melakukan kegiatan preservasi naskah kuno Syekh Abdul Manan melalui kegiatan pembatasan akses pengunjung terhadap naskah asli, pembersihan naskah dan lingkungan museum secara rutin, fumigasi, dan digitalisasi. Pembatasan akses secara langsung kepada pengguna berupa penyimpanan naskah kuno di etalase dan kotak khusus. Pembersihan rutin naskah dan museum melalui pengaturan cahaya dan kelembapan udara, penggunaan kamper di setiap sudut ruangan, pengaturan dehumidifier, dan pengarahan pengguna museum. Kegiatan fumigasi dilakukan melalui pengasapan menggunakan pestisida untuk menghilangkan hama sebanyak satu tahun sekali. Digitalisasi naskah kuno ke dalam bentuk buku digital (flipbook) yang dilakukan atas kerja sama museum dengan berbagai lembaga salah satunya peneliti dan mahasiswa dari Universitas Padjadjaran. Seluruh proses kegiatan preservasi dilakukan secara terstruktur dan terencana. Penelitian menyimpulkan bahwa pentingnya pelaksanaan preservasi oleh pihak museum adalah untuk menjaga dan melestarikan warisan naskah kuno agar dapat diakses dan dimanfaatkan masyarakat luas.
\end{abstract}

Kata Kunci: Naskah kuno; Preservasi; Museum Bandar Cimanuk 


\section{PENDAHULUAN}

Penyebaran agama Islam di Kabupaten Indramayu merupakan salah satu hal unik untuk didiskusikan karena pada awalnya mayoritas masyarakat Indramayu sebagai kerajaan yang bercorak Hindu dan Budha (Tabroni, Muhsin Z., Dienaputra, \& Mulyadi, 2020). Penyebaran agama Islam di Indramayu sendiri bermula dari masuknya para pedagang Arab melalui jalur pesisir pantai Indramayu. Hal ini banyak diceritakan melalui berbagai tulisan peninggalan masa lampau atau berupa sumber tradisional, di antaranya naskah kuno, babad, legenda, dan dongeng.

Naskah kuno atau manuskrip merupakan salah satu peninggalan sumber tradisonal yang menceritakan proses masuknya agama Islam ke Indramayu. Sebagian besar naskah kuno peninggalan leluhur ini sudah tersimpan di Museum Bandar Cimanuk, Indramayu, dan sebagian lainnya masih tersimpan di masyarakat. Adapun sebagian naskah yang masih dimiliki masyarakat, disimpan pada tokoh masyarakat yang dianggap sebagai tokoh tetua adat atau sesepuh adat.

Masyarakat memang masih menganggap tabu naskah kuno sebagai benda keramat, maka banyak naskah kuno rusak. Naskah kuno masih disimpan tanpa dirawat dengan baik sehingga beberapa naskah kuno rusak seperti, naskah kuno rapuh, naskah kuno menempel satu sama lain sehingga sulit dibuka dan dimanfaatkan para pengguna yang memerlukan data, dan naskah yang sudah tidak utuh lagi. Pengguna akan sulit mengakses naskah kuno yang mengalami kerusakan.

Kecamatan Indramayu termasuk salah satu tempat yang menyimpan banyak sekali peninggalan naskah kuno. Namun, masyarakat masih enggan membuka, memberikan, atau meminjamkan naskah kuno untuk mengungkapkan isi naskah kuno tersebut. Masyarakat masih menganggap naskah kuno benda keramat yang tidak boleh sembarang dibuka, maka banyak naskah kuno yang belum terungkap kandungan isi naskahnya.

Naskah kuno dapat dirawat dan disimpan sesuai kaidah preservasi. Apabila naskah kuno dalam kegiatan perawatan dan penyimpanannya tidak sesuai kaidah preservasi, maka naskah kuno akan rusak.

“Beberapa faktor yang menjadi perusak naskah kuno di antaranya pencahayaan ruangan yang tidak sesuai, penggunaan bahan kimia di sekitar naskah, faktor perusak berupa serangga, rayap dan lain sebagainya" (Khadijah, Rizal, Zulfan, Rejeki, \& Khoerunnisa, 2019).

Naskah kuno dapat rusak dari pengaturan cahaya, penggunaan kimia, dan serangga. Masyarakat dapat mengetahui beberapa faktor penyebab kerusakan naskah kuno di atas agar naskah kuno dijaga dan dirawat dengan baik. Naskah kuno yang sudah lapuk akan sangat rentan sobek dan sulit untuk diakses pengguna museum.

Naskah kuno yang disimpan di Museum Bandar Cimanuk merupakan naskah kuno yang menceritakan sejarah penyebaran agama Islam di Indramayu. Hal ini menandakan bahwa kandungan informasi naskah kuno sangat bernilai sejarah. Masyarakat khususnya generasi penerus melalui naskah kuno dapat mengetahui berbagai peninggalan sejarah dari para nenek moyang. 
Hendrawati (2014) mengatakan bahwa naskah kuno adalah, "Hasil tulisan tangan yang berisi informasi tentang budaya bangsa yang bernilai penting bagi kebudayaan nasional, sejarah, dan ilmu pengetahuan." Naskah kuno merupakan salah satu benda cagar budaya. Benda atau objek yang termasuk cagar budaya memiliki beberapa kriteria yang diatur Undang-Undang Republik Indonesia Nomor 11 Tahun 2010 Tentang Cagar Budaya (2010) di antaranya.

“(a) berusia 50 (lima puluh) tahun atau lebih; (b) mewakili masa gaya paling singkat berusia 50 (lima puluh) tahun; (c) memiliki arti khusus bagi sejarah, ilmu pengetahuan, pendidikan, agama, dan/atau kebudayaan; dan (d) memiliki nilai budaya bagi penguatan kepribadian bangsa."

Naskah kuno yang memiliki usia yang sudah lama dan memiliki kandungan sejarah, pendidikan, agama, dan budaya bagi suatu bangsa, maka wajib dilestarikan. Hal ini senada pernyataan Maryono and Pramono (2020) yang mengatakan bahwa naskah kuno atau mansukrip. “Dinilai memiliki arti khusus bagi sejarah, pendidikan serta kebudayaan yang dapat dijadikan sebagai penguatan kepribadian bangsa." Preservasi naskah kuno memang bukan hal yang mudah karena kita harus tetap menjaga keaslian naskah dan orisinalitas naskah. Hal ini mengingat usia naskah kuno sudah lama bahkan ada naskah yang mencapai ratusan tahun.

Pengguna museum untuk mengakses naskah kuno masih terbatas. Pengguna belum dapat mempelajari dan membaca naskah kuno secara langsung. Naskah kuno yang berusia ratusan tahun ketika disentuh akan memiliki risiko kerusakan fisik yang memengaruhi isi naskah tersebut.

"Penjagaan dan perawatan yang sangat ekstra perlu diperhatikan sebagai upaya untuk melestarikan naskah kuno agar naskah yang ada masih tetap dapat dinikmati dan informasi yang terkandung didalamnya dapat sampai kepada generasi penerus bangsa" (Amin, 2011).

Pada prinsipnya, naskah kuno sebagai bahan pustaka klasik yang memiliki nilai sejarah harus dilestarikan untuk kepentingan bangsa dalam jangka panjang. Untuk itu, perpustakaan dapat berperan membantu dalam kegiatan perawatan naskah kuno museum. Hal ini sesuai fungsi perpustakaan sebagai lembaga penyimpanan informasi dan penyimpanan karya budaya manusia suatu bangsa yang direkam dalam bentuk cetak dan rekam.

"Pelestarian atau preservasi bahan pustaka dapat dikatakan sebagai tabungan sumber informasi karena bila tidak dilakukan pelestarian bahan pustaka akan menghancurkan kekayaan perpustakaan dan hilangnya informasi. Lebih parah lagi, akan hilangnya warisan budaya bangsa" (Prastiani \& Subekti, 2017).

Naskah kuno sebagai bahan pustaka yang memiliki kandungan sejarah Indonesia yang harus lestari. Walaupun usaha perawatan bahan masih kurang mendapatkan perhatian di Indonesia. Padahal, perawatan bahan pustaka harus dilakukan lebih cermat mengingat Indonesia yang beriklim tropis, tidak menguntungkan pada kelestarian bahan pustaka.

Pada umumnya, sebagian besar bahan pustaka adalah bahan cetak terbuat dari 
bahan kertas. Bahan pustaka dari kertas tentu rentan mengalami kerusakan yang dapat disebabkan faktor internal dan faktor eksternal. Faktor internal adalah zat asam yang terkandung dalam kertas. Hal ini senada dengan pendapat Fatmawati (2017) yang menyatakan bahwa, “Zat asam dalam kertas terjadi karena sisa-sisa zat kimia yang tertinggal ketika pembuatan kertas." Adapun faktor eksternal dapat memengaruhi kerusakan bahan pustaka di antaranya adalah jamur, serangga, binatang pengerat, zat kimia, dan manusia. Oleh karena itu, bahan pustaka dapat bertahan lama dan informasi yang terkandung di dalam kertas dapat diakses secara utuh adalah, "Melalui pelestarian" (Fatmawati, 2017)

Naskah kuno sebelum teknologi dan informasi berkembang pesat sebagai salah satu bentuk teknologi masa lalu yang memuat informasi dari berbagai kejadian pada zaman tersebut. Naskah kuno merupakan tulisan tangan yang ditulis melalui media alami, seperti lontar, batu, dan kulit binatang. Naskah kuno yang dimiliki masyarakat, makin tidak terawat dan mengalami pelapukan. Hal ini dapat disebabkan faktor perawatan dan pengetahuan masyarakat yang minim. Naskah kuno agar berumur panjang, maka perlu dilakukan kegiatan preservasi.

Pada hakikatnya, preservasi naskah kuno adalah upaya merawat suatu sumber informasi atau, “Tindakan yang dilakukan seseorang, masyarakat, organisasi atau pemerintah dalam mencegah, memelihara dan mengawetkan naskah kuno" (Winoto, 2018). Secara umum, preservasi diartikan sebagai pelestarian. Pelestarian masih sangat luas cakupannya. Adapun kegiatan preservasi mencakup semua pertimbangan manajerial dan keuangan, termasuk ketentuan penyimpanan dan akomodasi, susunan staf, kebijakan, teknik dan metode pelestarian bahan perpustakaan serta informasi yang terkandung di dalamnya (Fatmawati, 2018).

Fatmawati (2018) menyatakan bahwa preservasi memiliki beberapa tujuan, antara lain penyelamatan informasi koleksi, penyelamatan fisik dokumen, dan mempermudah penelusuran koleksi. Pertama, preservasi untuk menyelamatkan nilai informasi dalam dokumen. Naskah kuno tentunya berisi berbagai informasi dan pengetahuan yang harus dijaga, contohnya naskah kuno Syekh Abdul Manan yang memiliki nilai informasi penyebaran Islam di Indramayu. Kemudian naskah ini memiliki informasi mengenai berbagai aqidah umat Islam dan ajaran tareqat nasabandriah.

Kedua, preservasi dilakukan untuk menyelamatkan fisik dokumen. Penyelamatan fisik dokumen dilakukan supaya keaslian fisik dokumen dapat tetap terjaga. Naskah kuno yang utuh secara fisik dapat mudah dipertanggungjawabkan. Ketiga, preservasi dilakukan untuk mempermudah penelusuran koleksi. Pihak museum melakukan digitalisasi naskah kuno berupa buku digital (flipbook) untuk memudahkan pengguna mengakses naskah kuno secara digital.

Preservasi merupakan perawatan sebuah koleksi. Naskah kuno sebagai koleksi museum harus dimanfaatkan untuk kepentingan pengetahuan sehingga memerlukan perlakuan dan perlindungan khusus. Selain itu, naskah kuno harus dijaga kandungan informasi yang dimiliki agar tetap terjaga dan dapat digunakan generasi berikutnya. Selama ini, pembatasan akses terhadap naskah kuno sudah beberapa kali dilakukan. Akan tetapi, upaya tersebut hanya dapat 
melestarikan kondisi naskah secara fisik saja. Pembatasan akses belum bisa mencegah kerusakan dari berbagai faktor lainnya, seperti kerusakan iklim, biota, hama, dan kerusakan dari bahan kimia dan lainnya.

Selain itu, naskah kuno rentan hilang, maka informasi dalam naskah pun akan hilang. Untuk menangani permasalahan ini, diperlukan kegiatan preservasi secara khusus terhadap naskah kuno tersebut. Preservasi yang dimaksud adalah penyelamatan naskah fisik dan penyelamatan informasi naskah yang terkandung di dalamnya. Pengguna museum harus dapat mengakses informasi dalam naskah, tanpa menyentuh langsung fisik naskah.

Penelitian mengenai naskah kuno telah berkembang. Salah satunya penelitian Christiani (2020) mengenai preservasi, konservasi, dan restorasi dokumen di Rekso Pustaka. Rekso Pustaka dalam melakukan kegiatan preservasi bekerja sama pada tataran level nasional dan internasional berupa pelestarian fisik dan isi dari bahan pustaka. Preservasi fisik dokumen dilakukan menggunakan cengkeh dan kapur barus untuk menghindari kerusakan fisik dokumen. Adapun preservasi isi dokumen dilakukan melalui proses transliterasi sebagai bentuk upaya konservasi dan pembuatan mikro film sebagai bentuk upaya restorasi.

Penelitian Christiani (2020) memiliki persamaan dan perbedaan dengan penelitian ini. Persamaan penelitian adalah sama-sama meneliti mengenai kegiatan preservasi koleksi museum, sedangkan perbedaan penelitian dalam lokasi penelitian, perbedaan kegiatan restorasi, dan perbedaan bentuk cagar budaya yang diteliti. Peneliti dalam penelitian ini tidak meneliti kegiatan konservasi dan restorasi, hanya meneliti kegiatan preservasi saja. Selain itu, bentuk cagar budaya yang dilakukan preservasi dalam penelitian ini naskah kuno, sedangkan penelitian Christiani (2020) meneliti naskah kuno, buku, dan dokumen milik Perpustakaan Rekso Pustaka.

Sesuai tinjauan penelitian terdahulu ini, penelitian mengenai naskah kuno masih sedikit yang meneliti. Penelitian preservasi naskah kuno Syekh Abdul Manan penting dilakukan karena mengingat peninggalan naskah kuno Syekh Abdul Manan merupakan naskah kuno yang menceritakan sejarah penyebaran islam di Indramayu. Masyarakat dan pemerintah daerah melalui naskah ini dapat mengetahui perkembangan sejarah Islam di Kabupaten Indramayu.

Selain itu, Museum Bandar Cimanuk sendiri merupakan museum yang dibangun atas inisiasi Yayasan Komunitas Indramayu Historia pada 2015. Hal ini menarik karena masyarakat, khususnya para budayawan bekerja sama membangun museum pertama di Indramayu. Museum ini menyimpan berbagai macam benda bersejarah, contohnya naskah kuno dari tingkatan usia yang berbeda-beda. Dengan demikian, penelitian ini bertujuan untuk mengetahui kegiatan preservasi naskah kuno Syekh Abdul Manan di Museum Bandar Cimanuk Indramayu.

\section{METODE PENELITIAN}

Penelitian ini menggunakan pendekatan kualitatif melalui metode penelitian deskriptif. Penelitian deskriptif adalah penelitian yang menempatkan peneliti sebagai instrumen kunci (Sugiyono, 2012). Peneliti mengumpulkan berbagai informasi mengenai data 
kegiatan pelaksanaan preservasi naskah kuno Syekh Abdul Manan di Museum Bandar Indramayu. Peneliti mengamati dan mengkaji berbagai hal yang dilakukan dalam menjaga kelestarian naskah kuno di Museum Bandar Cimanuk.

Objek penelitian adalah naskah kuno di Museum Bandar Cimanuk. Adapun subjek penelitian atau informan yang menjadi titik berat peneliti adalah Ketua Yayasan Komunitas Indramayu Historia dan pengurus Museum Bandar Cimanuk. Peneliti memilih informan penelitian menggunakan purposive sampling yakni menentukan informan sesuai kriteria penelitian. Adapun informan dipilih ialah informan yang memiliki kaitan dengan penemuan dan kegiatan perawatan naskah Syekh Abdul Manan di Museum Bandar Cimanuk, contohnya informan Ketua Komunitas Indramayu Historia yang menemukan naskah kuno Syekh Abdul Manan dan ikut mendirikan Museum Bandar Cimanuk.

Peneliti dalam teknik pengumpulan data, "Menggabungkan data dengan analisis data yang bersifat induktif" (Sugiyono, 2012). Peneliti mengobservasi, mewawancarai, dan melakukan studi literatur. Pertama, peneliti melakukan kegiatan observasi dengan berkunjung secara langsung ke Museum Bandar Cimanuk, Indramayu. Sugiyono (2012) menyatakan bahwa observasi sebagai teknik pengumpulan data yang memiliki ciri spesifik berkenaan dengan perilaku manusia, proses kerja, pengamatan gejala dengan informan yang diamati tidak terlalu besar. Peneliti melakukan observasi untuk melihat berbagai gejala, proses kerja, dan keadaan kegiatan preservasi Museum Bandar Cimanuk. Peneliti dalam mengobservasi kondisi museum menggunakan teknik observasi non partisipatory, merupakan sebuah observasi di mana peneliti tidak terlibat langsung dan hanya sebagai pengamat independen (Hasanah, 2016).

Kedua, peneliti melakukan kegiatan wawancara mendalam kepada ketua Yayasan Komunitas Indramayu Historia, pengurus dan pengunjung Museum Bandar Cimanuk. Pelaksanaan wawancara dilakukan secara semi terstruktur atau tidak terstruktur. Wawancara semi terstruktur dilakukan bertujuan agar tidak ada pertentangan (gap) antara peneliti dengan informan. Peneliti mewawancarai informan secara santai untuk memudahkan pemerolehan data dan mengembangkan pertanyaan saat dilakukan wawancara menggunakan panduan wawancara. Panduan wawancara berisi pertanyaan pokok yang sebelumnya sudah disiapkan dan wajib untuk ditanyakan kepada informan.

Ketiga, peneliti melakukan kegiatan studi literatur untuk memperkaya pengetahuan, mengkaji teori, dan memperkaya literatur ilmiah yang berkaitan dengan topik penelitian. Studi literatur atau studi pustaka merupakan kajian teoritis, referensi literatur ilmiah lainnya yang berkaitan dengan budaya, nilai dan norma yang berkembang pada situasi sosial yang diteliti (Sugiyono, 2012). Peneliti mengkaji penelitian terdahulu untuk membandingkan dan mencari informasi mengenai preservasi yang dilakukan berbagai instansi, seperti perpustakaan, museum, dan perseorangan. Studi literatur diambil dari berbagai sumber, antara lain jurnal, buku, dan literatur lain yang membahas mengenai preservasi naskah kuno di Indonesia.

Adapun peneliti dalam teknik analisis data melakukan reduksi data melalui 
pemilahan data yang didapatkan selama penelitian di Museum Bandar Cimanuk Indramayu. Peneliti pun melakukan teknik analisis data melalui triangulasi sumber data, yakni teknik menguji kembali kebenaran informasi tertentu dengan berbagai sumber data, contohnya dokumen, hasil wawancara, dan hasil observasi (Sugiyono, 2012). Peneliti melakukan konfirmasi data yang sudah didapatkan dari hasil wawancara, observasi, dan dokumen pendukung yang berkaitan dengan naskah kuno Syekh Abdul Manan.

\section{HASIL DAN PEMBAHASAN}

Syekh Abdul Manan merupakan kiai atau ulama yang tersohor pada masa Belanda. Kabupaten Indramayu merupakan daerah yang memiliki sejarah perjuangan Syekh Abdul Manan dalam menyebarkan dan mendidik masyarakat mengenai agama Islam. Sejarah agama Islam di Kabupaten Indramayu dapat berupa naskah yang dikenal sebagai naskah kuno Syekh Abdul Manan.

Naskah kuno Syekh Abdul Manan ditulis dalam sampul kulit kayu. Naskah ini saat ditemukan dalam kondisi usang dan sebagian sisi terdapat robekan. Meskipun demikian, tulisan naskah di dalamnya masih relatif jelas. Naskah ini ditulis menggunakan tulisan Arab Pegon atau Arab Gundul. Setelah peneliti amati, bahasa yang digunakan adalah bahasa Jawa yang biasa digunakan masyarakat Indramayu, yaitu bahasa Jawa Dermayu.

Naskah kuno Syekh Abdul Manan menceritakan gerakan yang dibawa Syekh Abdul Manan, yaitu thariqah naqsabandriah. Tariqah naqsabandriah masuk dari Cirebon yang awalnya dari Kalimantan kemudian menyebar ke Indramayu bagian barat (Iryana \& Lubis,
2018). Hal ini sesuai pernyataan informan bahwa thariqah naqsabandriah banyak diceritakan dalam naskah kuno Syekh Abdul Manan. "Baru terungkap sekitar beberapa saja dari total 7 naskah yang ditemukan" (S. Indrajaya, wawancara, August 14, 2018). Naskah kuno di Museum Bandar Cimanuk banyak digunakan sebagai pedoman penyebaran Agama Islam (Tabroni et al., 2020).

Naskah kuno Syekh Abdul manan saat ini berada di Museum Bandar Cimanuk, tepatnya di Jalan Veteran Kabupaten Indramayu. Pertama kali, naskah kuno ini ditemukan di sebuah musala kecil sebuah kecamatan Indramayu, tepatnya di daerah Panoman Indramayu. Penemu naskah kuno Syekh Abdul Manan adalah salah seorang informan yang melakukan inisiasi pembangunan Museum Bandar Cimanuk. Sesuai pernyataan informan, "Naskah ini diperkirakan berusia sekitar 1800 tahun. Kemarin ditransliterasikan dibantu Sanggar Aksara Jawa (S. Indrajaya, wawancara, August 14, 2018). Keberadaan naskah kuno Syekh Abdul Manan sangat penting. Untuk itu, penelitian ini melakukan analisis dalam kegiatan preservasi naskah kuno Syekh Abdul Manan di Museum Bandar Cimanuk Indramayu. Kegiatan preservasi dilakukan untuk menyelamatkan naskah dari kerusakan melalui langkah preservasi sesuai perencanaan dan kerja sama dengan pihak luar. Kegiatan ini diharapkan mampu melestarikan naskah kuno Syekh Abdul Manan dengan semua pertimbangan kondisi yang ada di museum ini.

Museum Bandar Cimanuk Indramayu sebelum melakukan kegiatan preservasi, akan melakukan perencanaan kegiatan, pengorganisasian, dan pelaksanaan. 
Perencanaan terdiri dari rancangan kapan pelaksanaan preservasi dilakukan, bagaimana proses pelaksanaan, berapa anggaran yang diperlukan, dan kerja sama dengan berbagai pihak. Pihak museum akan melakukan berbagai peluang yang memungkinkan dalam mencapai tujuan yang direncanakan.

Selain itu, pengorganisasian juga dilakukan sebagai proses untuk memastikan kebutuhan dan sumber daya yang dimiliki dalam pelaksanaan preservasi, misalnya penunjukan dan pemaparan tugas tim harian Sumber Daya Manusia (SDM) yang bertugas. Museum Bandar Cimanuk akan membagi pekerjaan kepada pengelola museum mengenai siapa yang memiliki kewajiban membersihkan naskah dari debu dan siapa yang bertugas melaksanakan fumigasi. Pihak museum dalam pelaksanaan preservasi, akan ada penyamaan visi dan misi. Kegiatan pelaksanaan bersumber dari perencanaan yang telah disusun sebelumnya. Hal ini memungkinkan sumber daya manusia yang tersedia dapat melakukan tugasnya secara baik dan sesuai kesepakatan bersama. Pelaksanaan Preservasi naskah kuno Syekh Abdul Manan di antaranya pembatasan akses pengunjung terhadap naskah asli, pembersihan rutin, fumigasi, dan digitalisasi.

Pertama, kegiatan pembatasan akses pengunjung terhadap naskah asli. Pihak Museum melakukan preservasi naskah kuno Syekh Abdul Manan di Museum Bandar Cimanuk Indramayu melakukan kegiatan pembatasan akses pengunjung terhadap naskah asli melalui penyimpanan naskah kuno dalam etalase kaca dan kotak khusus. Naskah kuno Museum Bandar Cimanuk Indramayu, termasuk naskah kuno Syekh Abdul Manan yang dipamerkan pada pengguna museum disimpan di ruang utama museum. Naskah kuno disimpan dalam etalase kotak berbahan dasar kaca pada gambar 1, di mana pengguna museum hanya dapat melihat naskah dari luar etalase. Pihak museum menyimpan naskah menggunakan etalase yang di ruang utama dilakukan untuk kenyamanan pengguna dan keamanan naskah. Selain itu, etalase digunakan untuk melindungi naskah dari sentuhan tangan para pengguna. Adapun dalam bagian depan etalase tertera informasi singkat naskah yang dapat dibaca pengguna museum (Apriliani, 2020).

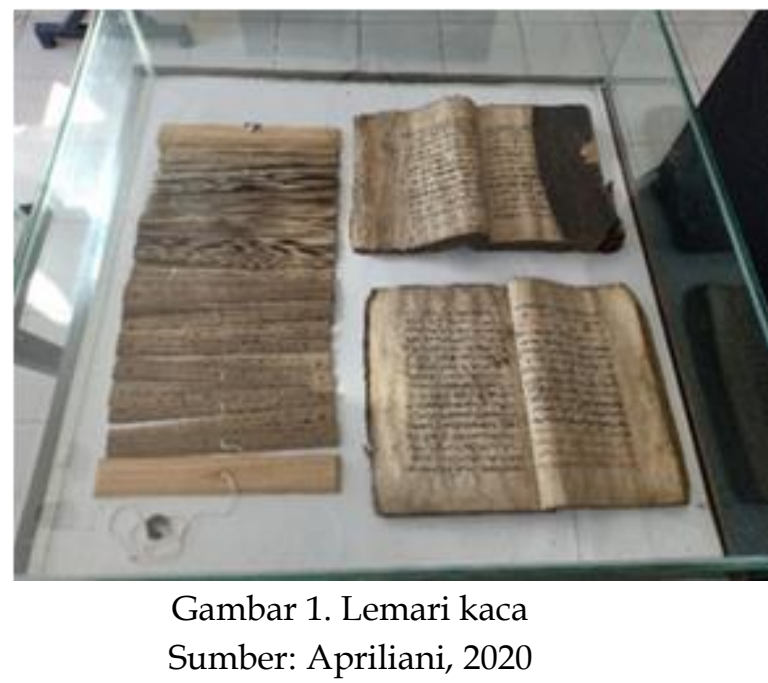

Pihak museum menyimpan naskah selain dalam etalase, juga menyimpan naskah pada kotak khusus yang berbahan kayu. Jadi, pihak museum memasukkan naskah kuno ke dalam kotak khusus. Kemudian, kotak khusus tersebut disimpan dalam lemari besar. Pihak museum menyimpan sebagian naskah dalam kotak khusus yang tersusun dalam lemari besar bertujuan agar naskah mudah ditemukan kembali. Naskah kuno dalam kotak kayu berjejer rapi, tidak menumpuk atau menyatu dengan naskah yang lain. Selain itu, kotak khusus berbahan kayu ini dapat mengurangi kelembapan udara, maka naskah akan tetap terjaga suhu udara dna 
suhu ruangan, tidak langsung terkena cahaya, dan tidak dapat dapat dijangkau serangga liar atau rayap (Apriliani, 2020).

Kedua, kegiatan pembersihan rutin. Pihak Museum Bandar Cimanuk Indramayu dalam kegiatan pembersihan rutin naskah kuno Syekh Abdul Manan melakukan pembersihan berkala yang dilakukan setiap pagi, pengaturan cahaya dan kelembapan udara yang masuk di museum, penggunaan kamper di setiap sudut ruangan, pengaturan dehumidifier, dan pemberian pengarahan (Apriliani, 2020). Pihak museum membersihkan naskah dan museum secara berkala yang dilakukan setiap pagi dengan cara membersihkan naskah dari debu yang tidak terlihat, melakukan pemeriksaan, menyapu seluruh lantai, dan mengelap kaca di setiap bagian museum.

Pihak Museum pun melakukan pengaturan cahaya dan kelembapan udara yang masuk di museum. Selain itu, pihak museum menggunakan kamper di setiap sudut ruangan, pengaturan dehumidifier, memberikan pengarahan kepada pengguna museum agar tetap menjaga kebersihan dan memperlakukan koleksi dengan baik, benar, dan bijak (Apriliani, 2020). Berdasarkan kegiatan pembersihan rutin di atas, pihak museum berusaha melindungi semua koleksi museum, khususnya naskah kuno Syekh Abdul Manan dari kerusakan.

Sesuai observasi di lapangan, kondisi naskah kuno Syekh Abdul Manan sedang mengalami kerusakan. Hal ini diperkuat pernyataan informan.

"Permasalahan di atas adalah kerusakan yang biasa terjadi pada naskah kuno, mengingat usia naskah yang sudah ratusan tahun lamanya sangat tidak mungkin jika naskah masih dalam kondisi yang utuh.
Pasalnya meskipun terjadi kerusakan isi dari naskah tidak mengalami banyak perubahan. Artinya, isi informasi masih dapat diakses dan terbaca, jika di persentasekan, tingkat keterbacaan-nya masih sekitar 7075\%" (S. Indrajaya, wawancara, August 14, 2018).

Naskah kuno Syekh Abdul Manan memang mengalami kerusakan di beberapa bagian. Namun, informasi dalam naskah tersebut masih dapat dibaca oleh pengguna. Hal ini dapat disebabkan sebagian besar masyarakat yang belum mengetahui cara merawat dan mengurus naskah kuno dengan baik dan benar

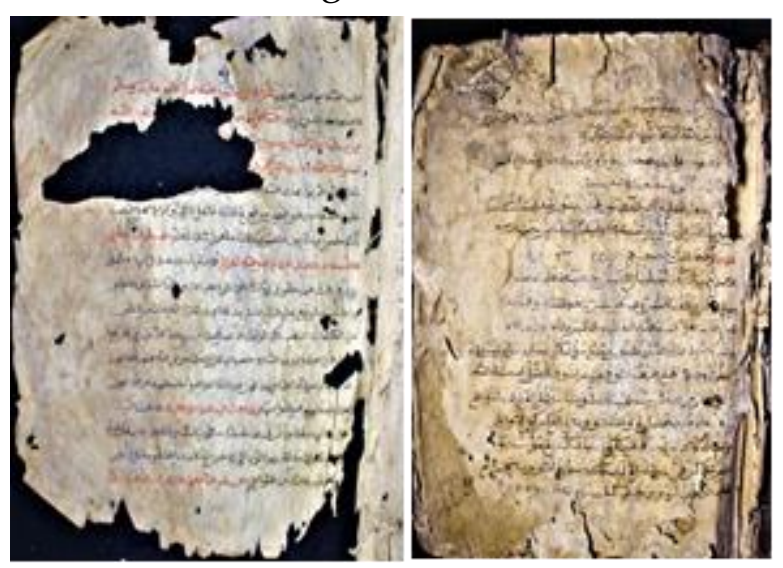

Gambar 2. Tampilan dua halaman naskah kuno Syekh Abdul Manan

Sumber: Apriliani, 2020

Pada gambar 2, merupakan contoh kerusakan pada naskah kuno Syekh Abdul Manan yang mengalami kerusakan disebabkan beberapa faktor perusak, antara lain faktor usia dan lingkungan. Sesuai faktor usia, naskah kuno syekh Abdul Manan diperkirakan memiliki usia naskah sekitar 1800-1900 tahun. Kerusakan utama ialah pelapukan kertas yang tidak dapat dipungkiri, seperti kertas berwarna kuning dan kecoklatan. Adapun faktor lingkungan, berkaitan dengan penyimpanan naskah kuno Syekh Abdul Manan yang pertama kali ditemukan 
dalam sebuah masjid di Kabupaten Indramayu.

Melihat kerusakan yang ada, pihak museum memiliki tanggung jawab sepenuhnya untuk merawat dan menjaga supaya koleksi tersebut tidak mengalami kerusakan yang semakin parah. Hal tersebut tentu memerlukan penanganan khusus yang nantinya memerlukan kegiatan konservasi dan restorasi guna memperbaiki kerusakan tersebut untuk menjaga agar kerusakan yang dialami tidak semakin melebar dan tidak semakin rusak. Kerusakan yang terjadi tersebut tentunya akan mempengaruhi keutuhan informasi yang terkandung dalam naskah kuno tersebut.

Ketiga, kegiatan fumigasi. Pihak Museum melakukan kegiatan fumigasi untuk mengendalikan hama yang dapat merusak naskah kuno. Fumigasi merupakan proses pengendalian hama yang dilakukan dengan cara pengasapan pestisida dalam bentuk gas. Fumigasi dilakukan satu tahun sekali melalui persetujuan dan anggaran khusus dari pengurus dan pengelola museum. Pihak museum ketika melakukan fumigasi, akan menutup sementara semua ruangan museum. Kegiatan Fumigasi ini dilakukan secara berkala dalam waktu tertentu karena memerlukan persiapan dan kesiapan dari pihak museum sendiri.

Keempat, digitalisasi. Pihak museum melakukan digitalisasi untuk melestarikan naskah kuno tanpa merusak isi naskah. Digitalisasi tidak dapat dilakukan pihak museum sendiri. Saat ini, pihak museum dalam kegiatan digitalisasi bekerja sama dengan dosen peneliti dan beberapa mahasiswa dari berbagai universitas, contohnya dosen dan mahasiswa dari Universitas Padjadjaran.
Museum Bandar Cimanuk melakukan digitalisasi dalam rangka mewujudkan upaya preservasi yang lebih luas dalam melestarikan naskah. Selain itu, naskah kuno melalui digitalisasi dapat mempertahankan isi naskah hingga bertahan lama dan dapat diketahui oleh generasi penerus bangsa di kemudian hari. Hasil digitalisasi naskah kuno Syekh Abdul Manan berbentuk buku digital (flipbook). Flipbook adalah lembaran kertas menyerupai album atau kalender berukuran kira-kira 21×28 cm. Flipbook juga dikenal sebagai digital book yang merupakan bentuk penyajian buku atau media belajar virtual (Rahmawati, Wahyuni, \& Yushardi, 2017).

Kegiatan digitalisasi naskah kuno di Museum Bandar Cimanuk melalui tiga alur kerja, antara lain, "Tahapan pra digitalisasi, tahapan digitalisasi, dan tahapan pasca (setelah) digitalisasi" (Hendrawati, 2014). Tahapan pra digitalisasi (prosedur awal) merupakan tahap persiapan sebelum pelaksanaan proses pengambilan objek digital. Hal ini bersifat persiapan administrasi.

Tahapan digitalisasi merupakan tindakan alih format suatu media ke format digital yang dimulai dengan proses pengambilan objek digital. Tahapan pasca (setelah) digitalisasi, menitikberatkan pada bagaimana objek digital disajikan dan diakses pengguna. Digitalisasi saat ini dilakukan masih pihak museum dengan kerja sama dengan berbagai pihak.

Kegiatan digitalisasi sesuai tahapan 3 alur kerja di atas, memiliki beberapa tujuan. Pertama, digitalisasi melalui alur kerja dapat berjalan secara sistematis dan terkontrol. kedua, digitalisasi melalui alur kerja dapat dilakukan pihak museum yang memahami dan menjalankan tugas masing-masing dengan baik. Digitalisasi 
naskah mencerminkan sebuah apresiasi dan tanggung jawab moral generasi saat ini terhadap warisan budaya intelektual dari nenek moyang (Nopriani \& Rodin, 2020).

Ketiga, pihak museum memiliki proses standarisasi atau penyamaan persepsi digitalisasi supaya pelaksanaan digitalisasi tidak salah dan sesuai prosedur alur kerja. Keempat, pihak museum dan staf memiliki peningkatan pengetahuan terhadap tahapan pelaksanaan kegiatan alih media, Kelima, pihak museum dan staf memiliki gambaran mengenai kegiatan alih media. Keenam, alur kerja sebagai panduan dalam melaksanakan kegiatan digitalisasi. Ketujuh, pengelola museum dan staf memiliki standar atau quality control dalam pelaksanaan digitalisasi.

Setelah, pihak museum melaksanakan alur kerja digitalisasi di atas, maka digitalisasi naskah kuno berbentuk flipbook dilakukan dalam beberapa tahap. Tahap digitalisasi pertama, persiapan berbagai peralatan yang digunakan dalam proses digitalisasi dan persiapan naskah kuno yang akan dilakukan digitalisasi (Apriliani, 2020). Pihak museum dan staf ketika proses penyiapan naskah harus berhati-hati jangan sampai proses digitalisasi merubah dan merusak naskah kuno yang asli.

Pihak museum saat membuka lembaran naskah kuno dapat menggunakan pin set, sebagai alat sentuh naskah. Hal ini bertujuan agar tidak terjadi kerusakan dan tidak memperparah robekan saat membuka lembaran naskah. Adapun peralatan yang digunakan dalam kegiatan digitalisasi adalah kamera digital, tripod, pin set, layar komputer atau laptop, dan penerangan yang cukup.

Tahap digitalisasi kedua, proses pengambilan gambar. Pengelola museum dan staf harus hati-hati karena flash kamera dapat memicu kerusakan naskah kuno. Hasil pengambilan gambar kemudian dipasangkan ke dalam layar komputer atau laptop. Gambar atau foto yang diambil sudah tidak buram atau blur, maka isi naskah sudah dapat terbaca jelas dan proses berikutnya dapat dilanjutkan. Namun apabila hasil pengambilan gambar belum sesuai, proses pengambilan gambar segera diulang kembali.

Tahap digitalisasi ketiga, proses edit. Setelah proses pengambilan gambar selesai, langkah selanjutnya koreksi gambar menggunakan perangkat lunak (software) edit. Proses edit tidak merubah komposisi isi gambar dan tidak menambah atau mengurangi halaman naskah. Hal ini dilakukan agar seluruh isi naskah sesuai kondisi aslinya.

Setelah tahapan digitalisasi selesai, data disatukan dalam sebuah file untuk diolah berupa flipbook. Pengguna museum dapat memanfaatkan flipbook untuk mengakses isi naskah kuno. Flipbook memiliki fitur yang sama dengan buku tercetak, namun flipbook berbentuk digital atau file. Pengguna museum dapat memperbesar gambar (zoom in) atau memperkecil gambar (zoom out) dari skala asli flipbook. Selain itu, flipbook memiliki fitur pencarian halaman, menampilkan halaman, dan fasilitas lainnya. Flipbook sebagai pengganti akses informasi naskah kuno yang diperlukan pengguna. Secara tidak langsung, flipbook dapat mewakili fungsi dokumen asli. Pengguna dapat mengakses naskah kuno bentuk digital, tanpa mengakses naskah secara asli secara langsung dengan cara membuka tiap halaman naskah. Flipbook sebagai solusi dalam mengurangi kerusakan naskah kuno yang terus menerus digunakan. 
Untuk itu, pihak museum dapat terus melakukan digitalisasi dan merawat naskah kuno asli. Naskah kuno ini adalah naskah langka yang berusia ratusan tahun sehingga pengguna ketika mengakses naskah kuno harus berhati-hati. Naskah kuno mengandung nilai informasi yang autentik. Ketika naskah kuno terjaga keaslian informasinya maka naskah kuno dapat tetap terjaga dan diakses pengguna museum. Pihak museum dapat melakukan kegiatan preservasi secara serius, termasuk naskah kuno syekh Abdul Manan.

Peneliti melihat bahwa upaya preservasi yang dilakukan pihak museum, dari pengurus dan pengelola museum sudah sangat maksimal dalam memanfaatkan berbagai upaya yang ada. Pihak museum sudah melakukan kegiatan preservasi harian hingga preservasi berjangka. Sesuai pemaparan di atas, preservasi naskah kuno Syekh Abdul Manan masih berfokus dalam preservasi naskah kuno secara fisik.

Pihak Museum Bandar Cimanuk Indramayu dalam melakukan kegiatan preservasi secara profesional sangat sulit dilakukan. Selain itu, pihak museum pun masih mengalami hambatan dalam setiap proses preservasi sehingga membuat preservasi museum tidak maksimal untuk dilakukan. Hambatan tersebut, di antaranya tidak adanya staf yang memiliki kemampuan khusus dalam melakukan preservasi, kurangnya sarana prasarana yang belum memadai dan belum mencapai standar kesiapan pelestarian. Meskipun demikian, pihak Museum Bandar Cimanuk tetap berusaha melakukan upaya yang maksimal dalam melakukan preservasi, demi menjaga warisan yang sudah ada dan dimiliki museum.
Untuk itu, preservasi naskah kuno di Museum Bandar Cimanuk Indramayu memerlukan sarana dan prasarana yang memadai. Pihak museum dapat terus melakukan digitalisasi dan merawat naskah kuno asli. Naskah kuno ini adalah naskah langka yang berusia ratusan tahun sehingga pengguna ketika mengakses naskah kuno harus berhati-hati. Naskah kuno mengandung nilai informasi yang autentik. Ketika naskah kuno terjaga keaslian informasinya maka naskah kuno dapat tetap terjaga dan diakses pengguna museum. Pihak museum dapat melakukan kegiatan preservasi secara serius, termasuk naskah kuno syekh Abdul Manan.

\section{SIMPULAN}

Pihak Museum Bandar Cimanuk telah melakukan kegiatan preservasi naskah kuno Syekh Abdul Manan melalui kegiatan pembatasan akses pengunjung terhadap naskah asli, pembersihan rutin, fumigasi, dan digitalisasi. Pembatasan akses secara langsung kepada pengguna berupa penyimpanan naskah kuno di etalase dan kotak khusus. Pembersihan rutin museum melalui pengaturan cahaya dan kelembapan udara, penggunaan kamper, dan pengarahan pengguna museum. Fumigasi dilakukan melalui pengasapan pestisida. Adapun pihak museum melakukan digitalisasi berbentuk buku digital (flipbook) yang dilakukan atas kerja sama dengan berbagai lembaga misalnya dengan peneliti dan mahasiswa dari Universitas Padjadjaran. Berdasarkan simpulan ini, pihak Museum Bandar Cimanuk telah berusaha melakukan kegiatan preservasi dalam memperpanjang usia dan informasi naskah kuno Syekh Abdul Manan. Untuk rekomendasi penelitian selanjutnya, 
penelitian dapat dikembangkan mengenai efektivitas penggunaan flipbook dalam pemahaman informasi naskah kuno pada pengguna museum.

\section{DAFTAR PUSTAKA}

Amin, F. (2011). Preservasi naskah klasik. Jurnal Khatulistiwa LP2M IAIN Pontianak, 1(1), 89-100. https://doi.org/10.24260/ khatulistiw a.v1i1.184

Apriliani, A. (2020). Pengembangan naskah kuno berbasis media flipbook digital dalam upaya pelestarian naskah kuno Islam Syekh Abdul Manan di Museum Bandar Cimanuk Indramayu (Skripsi). Universitas Padjadjaran, Sumedang.

Christiani, L. (2020). Preservasi, konservasi dan restorasi dokumen di Rekso Pustaka. Anuva: Jurnal Kajian Budaya, Perpustakaan, Dan Informasi, 4(3), 371382. Retrieved from https:/ / ejournal2.undip.ac.id/index. php/anuva/article/view/9472/4842

Fatmawati, E. (2017). Identification of factors causing damage to library collections (Identifikasi faktor-faktor penyebab kerusakan koleksi perpustakaan). EDULIB: Journal of Library and Information Science, 7(2), 108-119. Retrieved from https:/ / ejournal.upi.edu/index.php/ edulib/article/view/9722/5991

Fatmawati, E. (2018). Preservasi, konservasi, dan restorasi bahan perpustakaan. LIBRIA, 10(1), 13-32. Retrieved from https://jurnal.arraniry.ac.id/index.php/libria/article /view/3379/2370

Hasanah, H. (2016). Teknik-teknik observasi: Sebuah alternatif metode pengumpulan data kualitatif ilmuilmu sosial. Attaqaddum, 8(1), 21-46. https:/ / doi.org/10.21580/at.v8i1.116
3

Hendrawati, T. (2014). Pedoman pembuatan e-book dan standar alih media. Jakarta: Perpusnas PRESS. https://press.perpusnas.go.id/Produ kDetail.aspx?id=144

Iryana, W., \& Lubis, N. H. (2018). Perjuangan rakyat CirebonIndramayu melawan imprialisme. AlTsaqafa: Jurnal Ilmiah Peradaban Islam, 5(1), 89-98.

https://doi.org/10.15575/altsaqafa.v15i1.3038

Khadijah, U. L., Rizal, E., Zulfan, I., Rejeki, D. S., \& Khoerunnisa, L. (2019). Identifikasi faktor perusak pada naskah kuno di Situs Kabuyutan Ciburuy Garut. EDULIB: Journal of Library and Information Science, 9(2), 144-153. Retrieved from https://ejournal.upi.edu/index.php/ edulib/article/view/17865/pdf

Maryono, \& Pramono, M. (2020). Pengembangan website koleksi langka Perpustakaan UGM sebagai preservasi digital heritage menuju era industri 4.0. Jurnal Kajian Informasi $\mathcal{E}$ Perpustakaan, 8(1), 1 . https://doi.org/10.24198/jkip.v8i1.23 348

Nopriani, \& Rodin, R. (2020). Konservasi naskah manuskrip sebagai upaya menjaga warisan budaya bangsa di era industri 4.0. JUPITER, 17(1), 20-29. Retrieved from https://journal.unhas.ac.id/index.ph p/jupiter/article/view/11311/5833

Prastiani, I., \& Subekti, S. (2017). Digitalisasi manuskrip sebagai upaya pelestarian dan penyelamatan informasi: Studi kasus pada Museum Radya Pustaka Surakarta. Jurnal Ilmu Perpustakaan, 6(3), 141-150. Retrieved from 
https:// ejournal3.undip.ac.id/index. php/jip/article/view/23141/21167

Undang-Undang Republik Indonesia Nomor 11 Tahun 2010 Tentang Cagar Budaya. 24 November 2010. Lembaran Negara Republik Indonesia Tahun 2010 Nomor 130. Jakarta. Retrieved from https://jdih.kemdikbud.go.id/arsip/ UU_Tahun2010_Nomor11.pdf

Rahmawati, D., Wahyuni, S., \& Y. (2017). Pengembangan media pembelajaran flipbook pada materi gerak benda di SMP. Jurnal Pembelajaran Fisika, 6(4), 326-332.

https://doi.org/10.19184/jpf.v6i4.6213

Sugiyono. (2012). Memahami penelitian kualitatif. Bandung: Alfabeta.

Tabroni, R., Muhsin Z., M., Dienaputra, R. Z., \& Mulyadi, R. M. (2020). From tarekat to Arab community: The
Islamization process in Indramayu. Paramita: Historical Studies Journal, 30(1), 55-68. https://doi.org/10.15294/paramita.v 30i1.19947

Winoto, Y. (2018). Membangun kesadaran masyarakat Sumedang dalam melestarikan warisan budaya. LIBRARIA: Jurnal Perpustakaan, 6(1), 83-110.

https://doi.org/10.21043/libraria.v6i 1.3891 